\title{
Çocuk Gelişimi Lisans Öğrencilerinin Stres Düzeylerinin Sağlık Algısı Üzerine Etkisinin İncelenmesi
}

\author{
Investigation of Stress Levels of Child Development Undergraduate Students on Health Perception
}

\author{
Bayram DELEŞ ${ }^{1}$, Nazan KAYTEZ ${ }^{2}$
}

\begin{abstract}
ÖZ
Günümüzde stres bireylerin yaşamının her alanında ve her dönemde meydana gelebilmektedir. Özellikle sosyo-kültürel ve ekonomik değişimlerin hızlı yaşanması, bireylerin toplumsal yaşama uyum sorunlarını beraberinde getirmektedir. Bu sorunlar bireylerde strese neden olabilmektedir. Stres kontrol edilemediğinde ve yoğun olarak yaşandığında bireylerde sağlık problemlerine neden olabilmektedir. $\mathrm{Bu}$ araştırmada, çocuk gelişimi lisans öğrencilerinin stres düzeylerinin sağlık algısına etkisini ortaya koymak amaçlanmıştır. Araştırmada betimsel araştırma yöntemi ve tarama modeli kullanılmıştır. Araştırma Avrasya Üniversitesi Çocuk Gelişimi bölümünde öğrenim gören 395 öğrenci ile gerçekleştirilmiştir. Araştırmada veri toplama aracı olarak "Kişisel Bilgi Formu”, "Algılanan Stres Ölçeğì" ve "Sağlık Algısı Ölçeği’” kullanılmıştır. Araştırma sonucunda sınıf düzeyi artıkça algılanan stres ve sağlık algısı düzeyinin artığı, arkadaşlarıyla kalan öğrencilerin ailesiyle kalanlara kiyasla algılanan stres düzeylerinin daha yüksek olduğu, sigara içme sıklığı arttıkça algılanan stres düzeyinin yükseldiği yine bireyde kronik hastalık olması durumunda algılanan stres düzeyinin daha yüksek olduğu bulunmuştur. Araştırmada öğrencilerin algıladıkları stres düzeylerinin sağlık algısı düzeyleri üzerinde anlamlı etkiye sahip olduğu ve stres düzeyi arttıkça, sağlık algısını da arttığı sonucuna ulaşılmıştır.
\end{abstract}

Anahtar Kelimeler: Sağlık Algısı, Stres, Çocuk Gelişimi, Üniversite Öğrencileri

\begin{abstract}
Today, stress can occur in every area of individuals' lives and in every period. In particular, the rapid socio-cultural and economic changes, bring about the problems of individuals' adaptation to social life. These problems can cause stress in individuals. When stress cannot be controlled and experienced intensely, it can cause health problems in individuals. In this study, it is aimed to reveal the effect of stress levels of child development undergraduate students on health perception. Descriptive research method and scanning model were used in the research. The research was carried out with 395 students studying at the Department of Child Development of Avrasya University. "Personal Information Form", "Perceived Stress Scale" and "Health Perception Scale" were used as data collection tools in the research. As a result of the study, it was found that the level of perceived stress and health perception increased, the perceived stress levels higher compared to the students who stayed with their friends, and the higher the perceived stress level in case of chronic disease, as the frequency of smoking increases. In the study, it is concluded that the stress levels perceived by the students had a significant effect on the levels of health perception, and as the stress level increased, the perception of health increased.
\end{abstract}

Keywords: Health Perception, Stress, Child Development, University Students

${ }^{1}$ Doktora Öğrencisi, Çocuk Gelişimi ABD, Ankara Üniversitesi, Sağlık Bilimleri Enstitüsü delesbayram@gmail.com, ORCID:0000-00027507-240X

${ }^{2}$ Dr. Öğr. Üyesi, Çocuk Gelişimi Bölümü, Çankırı Karatekin Üniversitesi, Sağlık Bilimleri Fakültesi nznunal@hotmail.com, ORCID: 00000001-8232-8947

İletişim / Corresponding Author: 


\section{GíRIŞ}

Günümüzde bireysel ve toplumsal yaşamda önemli değişiklikler hızlı bir şekilde gerçekleşmektedir. $\mathrm{Bu}$ değişimler şehir içi, şehirlerarası ve bölgeler arası göçler, nüfus artışı, işsizlik, teknolojik gelişmeler, sosyo-kültürel çatışmalar şeklinde gerçekleşmektedir. ${ }^{1}$ Meydana gelen değişimler sonucunda, bireylerin yaşam algıları, değerleri, sosyal ve ekonomik ilişkileri, gelecek planları da farklılaşmaktadır. Bireyler çevrelerinde gerçekleşen hızlı değişimlere uyum sağlamak durumunda kalmakta ve bu süreçte stres yaşamaktadırlar. ${ }^{2,3}$

Stres bireyleri huzursuz eden ve belirli bir seviyenin üstüne çıktığında ya da yoğun olarak yaşandığında bireylerde psikolojik ve fizyolojik rahatsızlıklara neden olan bir durumdur. ${ }^{4}$ Stres kontrol edilemediğinde bireylerde karar verme, endişe, yetersizlik duygusu, hafıza problemleri, tükenmişlik hissi, mutsuzluk, agresiflik gibi durumlara da neden olabilmektedir. ${ }^{5}$ Yapılan araştırmalarda stresin birey üzerindeki olumsuz etkilerini ortaya koymaktadır. Birçok araştırmada bireylerin stres düzeyleri ile uyku, beslenme düzeni, fiziksel aktivite ve zararlı madde kullanımı arasında anlamlı bir farklılık olduğu saptanmıştır. ${ }^{6,7}$ Stresin ilişkili olabileceği faktörlerden birisi de sağlık algısıdır. Stresin sağlığa zararlı olduğu ve genel olarak sağlık davranışları üzerinde etkili olduğu bilinmektedir. ${ }^{8}$ Çapık (2006)'a göre stresin genel olarak sağlık üzerinde olumsuz etkileri bulunmaktadır., ${ }^{1,5}$ Yine stres yaşayan bireylerde yaşanan strese ve stresin sonuçlarına bağlı olarak sağlık algılarında değişiklikler meydana gelebilmektedir.

Sağlık algısı bireylerin kendi sağlıkları ile ilgili hislerini ifade etmektedir. Bu hisler kendini iyi hissetme, sağlıklı beslenme, zararlı alışkanlıklardan uzak durma gibi davranışlarla ilişkilidir. $\mathrm{Bu}$ davranışlar geçmişten günümüze, toplumdan topluma değişiklik gösterebilmektedir. Hatta aynı toplumda farklı yaş grupları arasında da değişiklik görülebilmektedir. Bu gruplardan birisi de ergenlerdir. ${ }^{9}$

Ergenlik dönemi bireyde fizyolojik ve psikolojik değişikliklerin meydan geldiği önemli bir dönemdir. Ergenlik dönemine denk gelen üniversite yılları ise ergenin ailesinden uzaklaştığ 1 , yeni bir çevre edindiği, romantik ilişkilerin ön plana çıktığı, ders çalışma, ders geçme, mezun olma kaygısının yoğun olarak yaşandığ 1 yıllardır. ${ }^{10}$ Üniversite öğrenciliği, sosyokültürel ve ekonomik değişimlerin belirgin hale geldiği bir dönemdir. ${ }^{2,11}$ Öğrenciler bu dönemde kendi sorumluluklarının farkına varırlar, geleceğe yönelik planlar yaparlar, iş ve gelecek kaygısı yaşamaya başlarlar., ${ }^{4,12}$ Yaşanılan bu kayg1 öğrencilerde strese neden olabilmekte, stres de beraberinde çeşitli sağlik sorunlarını getirebilmektedir. ${ }^{13,14}$ Öğrencilerin sağlık sorunları ile baş edebilmesinde de sağlık algıları önemli rol oynamaktadır. $\mathrm{Bu}$ araştırma, çocuk gelişimi öğrencilerinin stres düzeylerinin sağlık algılarına etkisini ortaya koymak amaciyla gerçekleştirilmiştir. Araştırmanın amacına bağlı olarak aşağıdaki alt problemlere yanıt aranmıştır;

- $\quad$ Öğrencilerin algılanan stres ve sağlık algısı ölçeğinden aldıkları puanlar ile cinsiyet, sinıf düzeyi, barınma şekli, sigara içme durumu, ailede ve bireyde kronik hastalık durumu gibi değişkenler arasında anlamlı farklılık bulunmakta midır?

- $\quad$ Öğrencilerin algılanan stres düzeylerinin sağlık algısı üzerinde anlamlı etkisi var midır? 


\section{MATERYAL VE METOT}

\section{Araştırmanın Tipi}

Çocuk gelişimi lisans öğrencilerinin stres düzeylerinin, sağlık algısı üzerine etkisinin incelendiği araştırmada betimsel araştırma yöntemi ve tarama modeli kullanılmıştır. Tarama modeli, çalışmaya dahil edilen bireyleri veya nesneleri kendi koşulları ile var olduğu gibi tanımlamayı amaçlayan araştırma yaklaşımıdır. ${ }^{15}$

\section{Araştırmanın Evren ve Örneklemi}

Araştırmanın evrenini 2019-2020 eğitim-öğretim y1lı bahar döneminde, Avrasya Üniversitesi Çocuk Gelişimi bölümünde öğrenim gören 410 öğrenci oluşturmaktadır. Araştırmanın örneklemini ise evren içerisinden rasgele örnekleme yöntemiyle seçilen 395 öğrenci oluşturmaktadır. Araştırmada gönüllü katılım sağlanmıştır.

Araştırmaya alınan öğrencilerin \%87,03'ü kadın, \%13,07'si erkektir. Öğrencilerin \%36,07'si 1. sinıf, \%42,08'i 2. sinif, \%8,09'u 3. sinif ve \%11,06'sı 4. sinifa devam etmektedir. Öğrencilerin \%64,08'i ailesiyle, $\quad \% 21,08$ 'i yurtta (Devlet/özel/pansiyon vb), \%8,06's1 arkadaşlarıyla, \%2,08'i yalnız, \% 2'si ise akrabalarıyla yaşamaktadır. Sigara kullanma durumları ile ilgili olarak öğrencilerin \%64,06's1 hiç içmedim, $\% 2,08$ 'i bıraktım, \%17,07'si ara sıra içiyorum, \%14,09'u her gün içiyorum yanıtını vermiştir. Öğrencilerin büyük bir çoğunluğunun $(\% 87,06)$ kronik bir hastalığ1 bulunmamaktadir. Yine \%53,09'unun ailesinde kronik bir hastallk bulunmazken, $\% 46,01$ 'inin ailesinde kronik bir hastalık bulunmaktadır. Beslenme durumları ile ilgili olarak öğrencilerin $\% 56,05$ 'i kısmen sağlıklı besleniyorum, \%28,04'ü sağlıklı besleniyorum, $\% 8,09$ 'u sağliklı beslenmiyorum, \%6,03'ü ise herhangi bir fikrim yok yanıtını vermiştir.

\section{Veri Toplama Araçları}

Araştırma verilerinin toplanması aşamasında "Kişisel Bilgi Formu', "Algilanan Stres Ölçeği”, ve "Sağlik Algısı Ölçeği", kullanılmıştır. Ölçeklerin kullanımı için 26 Mart 2020 tarihinde ilgili yazarlardan gerekli izinler alınmıştır.

Kişisel Bilgi Formu'nda, öğrencilerin sınıf düzeyi, cinsiyet, barınma şekli, sigara kullanma durumu, ailede ve kendisinde kronik hastalık olma durumuna ilişsin sorular yer almaktadır.

Algılanan Stres Ölçeği, bireylerin algıladıkları stres düzeylerini belirlemek amaciyla Cohen vd. (1983) tarafindan geliştirilmiştir. ${ }^{16}$ Ölçeğin cronbach alpha güvenirlik katsayısı 0,78 olarak bulunmuştur. Ölçek 10 maddeden oluşmaktadır. Her madde "Hiçbir zaman (0)", "Neredeyse hiçbir zaman (1)", "Bazen (2)", "Oldukça sık (3)" ve "Çok sık (4)" şeklinde değişen 5'li likert tipi derecelendirmeye sahiptir. Ölçeğin Türkçeye uyarlaması Erci (2006) tarafindan yapılmış olup cronbach alpha güvenirlik katsayıs1 .88 olarak bulunmuştur. ${ }^{17}$

Sağlık Algısı Ölçeği, Diamond ve arkadaşları (2007) tarafindan geliştirilmiştir. ${ }^{18} 15$ maddeden oluşan ölçeğe verilen yanitlar "Tamamen katılıyorum (5)", "Katıliyorum (4)", "Kararsızım (3)", "Katılmıyorum (2)", "Hiç katılmiyorum (1)" şeklinde derecelendirilmektedir. Ölçeğin Türkçeye uyarlaması Kadığlu ve Yıldız (2012) tarafından gerçekleştirilmiştir. Ölçeğin cronbach alpha güvenirlik katsayısı $\quad 82$ olarak bulunmuştur. ${ }^{11}$

\section{Araștırmanın Etik Yönü}

Araştırmaya başlamadan önce öğrencilerin eğitim gördüğü Avrasya Üniversitesi Sağlık Bilimleri Fakültesi Dekanlığı'ndan 02.04.2020 tarihli ve 57443978-199.00-543 sayılı kararla gerekli izin alınmıştır. Daha sonra Gümüşhane Üniversitesi Etik Kurulundan 07.04.2020 
tarihli ve 2020/4 sayılı kararı ile çalışmanın yürütülebilmesi için gerekli izin alınmıştır. Araştırmaya alınan öğrencilere araştırmanın amacı anlatılmış ve onam formu alınarak çalışma gerçekleştirilmiştir.

\section{Verilerin Toplanması}

Araştırma için ilgili kurumlardan ve ölçek sahiplerinden gerekli izinler alındıktan sonra veri toplama araçları ve onam formu pandemi dolayısıyla dijital ortamda öğrencilere ulaştırılmıştır. Araştırma verileri 09-16 Nisan 2020 tarihleri arasında toplanmıştır. Araştırmada verilerin dijital ortamda toplanması çok sayıda öğrenciye ulaşımını engellemiştir. $\mathrm{Bu}$ araştırmanın sınırlılığıdır. Dijital ortamda toplanan veriler kontrol edilmiş eksik doldurulan veri toplama araçları araştırmaya dâhil edilmemiştir.

\section{Verilerin Analizi}

Araştırmada SPSS24 veri analiz programı kullanılmıştır. Öğrencilerin sosyo-demografik özellikleri frekans ve yüzde olarak verilmiştir. Algılanan Stres Ölçeği ve Sağlık Algısı Ölçeği'nden elde edilen veriler "T testi, Anova testi ve Regresyon analizleri” ile test edilmiştir.

\section{BULGULAR VE TARTIŞMA}

Öğrencilerin algılanan stres ve sağlık algısı ölçeğinden aldıkları puanlar cinsiyet ve sağlıklı beslenme durumları açısından incelendiğinde anlamlı bir farklılığın ortaya çıkmadığı saptanmıştır $(\mathrm{p}>0,05)$. Sınıf değişkenine göre öğrencilerin Algılanan Stres ve Sağlık Algısı Ölçeği'nden aldıkları puanlarına ilişkin sonuçlar aşağıda verilmiştir (Tablo 1).

Tablo 1.Öğrencilerin Algılanan Stres ve Sağlık Algısı Puanlarının Sınıf Değişkenine Göre Anova Testi Sonuçları

\begin{tabular}{|c|c|c|c|c|c|c|c|}
\hline Ölçekler & Sınıf Düzeyi & $\mathbf{N}$ & Ort. & SS & sd & $\mathbf{F}$ & $\mathbf{p}$ \\
\hline \multirow{4}{*}{$\begin{array}{l}\text { Algilanan } \\
\text { Stres }\end{array}$} & 1 & 145 & 30,89 & 4,225 & \multirow{4}{*}{3} & \multirow{4}{*}{1,005} & \multirow{4}{*}{$\begin{array}{r}, 015 * \\
1,2,3-4\end{array}$} \\
\hline & 2 & 169 & 31,11 & 4,957 & & & \\
\hline & 3 & 35 & 31,51 & 3,023 & & & \\
\hline & 4 & 46 & 33,04 & 3,753 & & & \\
\hline \multirow{5}{*}{ Sağlık Algısı } & 1 & 145 & 44,71 & 6,290 & \multirow{4}{*}{3} & \multirow{4}{*}{2,331} & \multirow{4}{*}{$\begin{array}{r}, 001 * \\
1,2,3-4 \\
1-2,1-3\end{array}$} \\
\hline & 2 & 169 & 46,81 & 6,294 & & & \\
\hline & 3 & 35 & 47,00 & 6,183 & & & \\
\hline & 4 & 46 & 48,45 & 5,540 & & & \\
\hline & Toplam & 395 & & & & & \\
\hline
\end{tabular}

Öğrencilerin algılanan stres ve sağllk algıs1 ölçeğinden aldıkları puanlar sınıf değişkenine göre incelendiğinde, öğrenci grupları arasında anlamlı farklılığın ortaya çıktığ 1 saptanmıştır $(\mathrm{p} \leq 0,05)$. Anlamlı farklılığa ilişkin posthoc testi sonuçları incelendiğinde algılanan stres ölçeğinde, 1 ., 2. ve 3. sınıf grubunda yer alan öğrenciler ile 4. sinif grubunda yer alan öğrenciler arasında anlamlı bir farklılığın ortaya çıktığı saptanmıştır. Dolayısıyla 4. sınıf grubunda yer alan öğrencilerin stres düzeyleri diğer sınıf gruplarında yer alan öğrencilere göre anlamlı ölçüde daha yüksektir. Sağlık algısı ölçeğinde ise 1., 2. ve 3. sınıftaki öğrenciler ile 4. sinıftaki öğrenciler arasında 4. sınıf olan öğrenciler açısından anlamlı bir farklılığın ortaya çıktığ1 saptanmıştır. Ayrıca 1. sınıftaki öğrencilerle 2. ve 3. sinıftaki öğrenciler arasında 2. ve 3. sinıftaki öğrenciler açısından anlamlı bir farklılığın ortaya çıktığı saptanmıştır. Dolayısıyla 2 ve 3 . sinıflarda okuyan öğrencilerin 1 . sinıftakilere göre, 4. sinıfta okuyan öğrencilerin ise diğer tüm sınıflara göre 
sağlık alg1sı düzeyleri anlamlı ölçüde daha yüksektir. Öğrencilerin sınıf düzeyleri arttıkça sağlık algısı düzeyleri de artış göstermektedir (Tablo 1).

Öğrencilerin algilanan stres ölçeğinden aldıkları puanlar barınma şekline göre incelendiğinde, gruplar arasında anlamlı farklılığın ortaya çıktığı saptanmıştır $(p \leq 0,05)$. Anlamlı farklılığa ilişkin posthoc testi sonuçları incelendiğinde ailesiyle yaşayanlar ile arkadaşlarıyla yaşayanlar arasında anlamlı farklılık bulunmuştur. $\mathrm{Bu}$ farklılıklara ilişkin aritmetik ortalama puanları incelediğinde arkadaşlarıyla kalan öğrencilerin algılanan stres düzeylerinin daha yüksek olduğu görülmektedir. Buna karşılık sağlık algısı ölçeğinden alınan puanlar arasinda anlamlı farklılık bulunmamıştır ( $p>0,05)$ (Tablo 2).

Tablo 2. Öğrencilerin Algılanan Stres ve Sağlık Algısı Puanlarının Barınma Şekli Değişkenine Göre Anova Testi Sonuçları

\begin{tabular}{|c|c|c|c|c|c|c|c|}
\hline Ölçekler & Barınma Şekli & $\mathbf{N}$ & Ort. & SS & sd & $\mathbf{F}$ & $\mathbf{p}$ \\
\hline \multirow{5}{*}{$\begin{array}{l}\text { Algılanan } \\
\text { Stres }\end{array}$} & Ailemle yaşıyorum $^{1}$ & 256 & 30,83 & 4,615 & \multirow{5}{*}{4} & \multirow{5}{*}{1,392} & \multirow{5}{*}{$\begin{array}{r}, 036 * \\
3-1\end{array}$} \\
\hline & Akrabalarımla $^{2}$ & 8 & 31,00 & 2,672 & & & \\
\hline & Arkadaşlarımla $^{3}$ & 34 & 32,50 & 4,047 & & & \\
\hline & ${\text { Yaln } 1 z^{4}}^{4}$ & 11 & 30,00 & 1,788 & & & \\
\hline & $\begin{array}{l}\text { Yurtta } \\
\text { (Devlet/özel/pansiyon vs) }\end{array}$ & 86 & 31,44 & 4,258 & & & \\
\hline \multirow{6}{*}{$\begin{array}{l}\text { Sağlık } \\
\text { Algısı }\end{array}$} & Ailemle yaşıyorum & 256 & 45,62 & 6,057 & \multirow{5}{*}{4} & \multirow{5}{*}{, 059} & \multirow{5}{*}{,994 } \\
\hline & Akrabalarımla & 8 & 45,12 & 8,903 & & & \\
\hline & Arkadaşlarımla & 34 & 45,41 & 6,025 & & & \\
\hline & Yalniz & 11 & 44,81 & 5,671 & & & \\
\hline & $\begin{array}{l}\text { Yurtta } \\
\text { (Devlet/özel/pansiyon vs) }\end{array}$ & 86 & 45,55 & 6,741 & & & \\
\hline & Toplam & 395 & & & & & \\
\hline
\end{tabular}

Öğrencilerin algılanan stres ölçeğinden aldıkları puanlar sigara kullanma durumu açısından incelendiğinde, gruplar arasında anlamlı farklılığın ortaya çıktığı saptanmıştır $(\mathrm{p} \leq 0,05)$. Anlamlı farklılı̆̆a ilişkin posthoc testi sonuçları incelendiğinde hiç sigara içmeyenlerle ara sıra içenler ve her gün içenler, ara sıra sigara içenlerle de her gün içenler arasında anlamlı farklılık bulunmuştur. $\mathrm{Bu}$ farklılıklara ilişkin aritmetik ortalama puanları incelediğinde sigara içme sıklığı arttıkça algılanan stres düzeylerinin yükseldiği saptanmıştır. Buna karşılık sigara kullanma durumu ile öğrencilerin sağlık algısı ölçeğinden alınan puanlar arasında anlamlı farklılığın ortaya çıkmadığı saptanmıştır (p>0,05) (Tablo 3).

Tablo 3.Öğrencilerin Algılanan Stres ve Sağlık Algısı Puanlarının Sigara Kullanma Durumuna Göre Anova Testi Sonuçları

\begin{tabular}{|c|c|c|c|c|c|c|c|}
\hline Ölçekler & Sigara İçme Durumu & $\mathbf{N}$ & Ort. & SS & sd & $\mathbf{F}$ & $\mathbf{p}$ \\
\hline \multirow{4}{*}{$\begin{array}{l}\text { Algılanan } \\
\text { Stres }\end{array}$} & Hiç içmedim ${ }^{1}$ & 255 & 30,55 & 4,614 & \multirow{4}{*}{3} & \multirow{4}{*}{4,899} & \multirow{4}{*}{$\begin{array}{r}, 002 * \\
1-3 \\
1-4 \\
3-4\end{array}$} \\
\hline & Bıraktım $^{2}$ & 11 & 30,09 & 3,300 & & & \\
\hline & Ara sıra içerim ${ }^{3}$ & 70 & 31,78 & 3,313 & & & \\
\hline & Her gün içerim $^{4}$ & 59 & 32,74 & 4,451 & & & \\
\hline \multirow{5}{*}{ Sağlık Algısı } & Hiç içmedim & 255 & 45,29 & 6,259 & \multirow{4}{*}{3} & \multirow{4}{*}{,619 } & \multirow{4}{*}{,603 } \\
\hline & Biraktım & 11 & 46,72 & 7,524 & & & \\
\hline & Ara sıra içerim & 70 & 46,31 & 6,614 & & & \\
\hline & Hergün içerim & 59 & 45,55 & 5,405 & & & \\
\hline & Toplam & 395 & & & & & \\
\hline
\end{tabular}


Öğrencilerin algılanan stres ölçeğinden aldıkları puanlar kronik hastalıkları olmadurumu açısından incelendiğinde, gruplar arasında anlamlı farklılı̆̆ın ortaya çıktı̆̆ 1 saptanmıştır $(p \leq 0,05)$. Farklılığın nereden kaynaklandığ incelendiğinde kronik hastalığılan öğrencilerin algıladıkları stres düzeyinin daha yüksek olduğu saptanmıştır. Buna karşsılık kronik hastalık olma durumu ile sağlı algis1 ölçeğinden alınan puanlar arasında anlamlı farklılığın ortaya çıkmadığı tespit edilmiştir $(p>0,05)$. Öğrencilerin algılanan stres ölçeğinden ve sağlık algısı ölçeğinden aldıkları puanlar ailede kronik hastalık olma durumu değişkeni bakımından incelendiğinde gruplar arasında anlamlı farklılığın ortaya çıkmadığı saptanmıştır $(\mathrm{p}>0,05)$ (Tablo 4).

Tablo 4. Öğrencilerin Algılanan Stres ve Sağlık Algısı Puanlarının Bireyde ve Ailesinde Kronik Hastalık Olma Durumuna Göre t Testi Sonuçları

\begin{tabular}{|c|c|c|c|c|c|c|c|}
\hline Ölçekler & $\begin{array}{l}\text { Bireyde } \\
\text { hastalık } \\
\text { durumu }\end{array}$ & $\mathbf{N}$ & Ort. & SS & $\mathbf{t}$ & sd & $\mathbf{p}$ \\
\hline \multirow{2}{*}{$\begin{array}{l}\text { Algılanan } \\
\text { Stres }\end{array}$} & Hayır & 346 & 30,86 & 4,334 & \multirow{2}{*}{$-2,667$} & \multirow{2}{*}{393} & \multirow{2}{*}{,008 } \\
\hline & Evet & 49 & 32,65 & 4,754 & & & \\
\hline \multirow{3}{*}{$\begin{array}{l}\text { Sağlık } \\
\text { Algısı } \\
\end{array}$} & Hayır & 346 & 45,52 & 6,305 & \multirow{2}{*}{,- 311} & \multirow{2}{*}{393} & \multirow{2}{*}{,756 } \\
\hline & Evet & 49 & 45,81 & 5,739 & & & \\
\hline & $\begin{array}{l}\text { Ailede } \\
\text { hastalık } \\
\text { durumu }\end{array}$ & & & & & & \\
\hline \multirow{2}{*}{$\begin{array}{l}\text { Algılanan } \\
\text { Stres }\end{array}$} & Hayır & 213 & 31,18 & 4,637 & \multirow{2}{*}{,459 } & \multirow{2}{*}{393} & \multirow{2}{*}{,646 } \\
\hline & Evet & 182 & 30,97 & 4,165 & & & \\
\hline \multirow{2}{*}{$\begin{array}{l}\text { Sağlık } \\
\text { Algısı }\end{array}$} & Hayır & 213 & 45,74 & 6,446 & \multirow{2}{*}{ 653 } & \multirow{2}{*}{393} & \multirow{2}{*}{, 514} \\
\hline & Evet & 182 & 45,33 & 5,981 & & & \\
\hline
\end{tabular}

Öğrencilerin stres düzeylerinin sağlık algısı düzeyleri üzerine etkisi regresyon analizi ile test edilmiştir. Yapılan analiz sonucunda stresin sağlık algısı üzerindeki etkisi $\% .17$ olarak bulunmuştur $(p \leq 0,05$;
F:12,233). Puanlar incelendiğinde katılımcıların stres düzeyinin artmasının sağlık algısı üzerinde olumlu etki meydana getirdiği saptanmıştır (t: 3,498; p: ,001 $\mathrm{p} \leq 0,05$ ) (Tablo 5).

Tablo 5.Öğrencilerin Algılanan Stresin Sağlık Algısı Puanlarına Etkisine İlişkin Regresyon Analizi Sonuçları

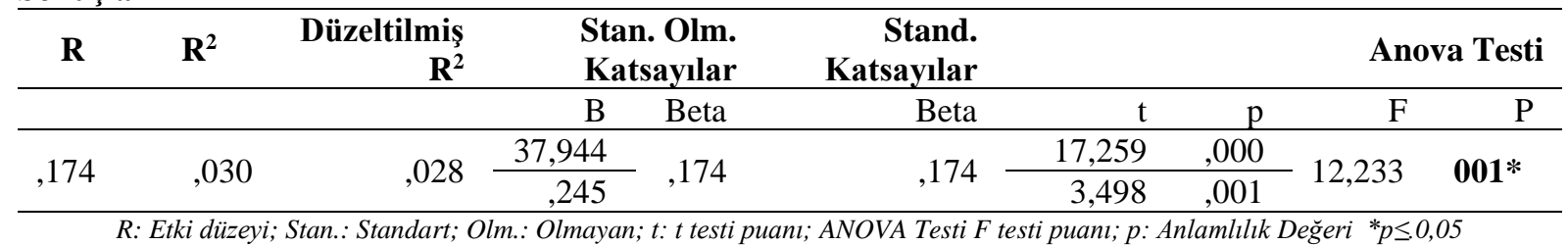

Araştırmada öğrencilerin algılanan stres ve sağlık algısı ölçeği puanlarına göre cinsiyet değişkeni arasında anlamlı farklılığın ortaya çıkmadığı saptanmıştır. $\mathrm{Bu}$ sonuç erkek ve kadın öğrencilerin benzer sağlık algılarına sahip olduklarını göstermektedir. Benzer şekilde Özdelikara vd. (2018), Lee (2019), Çilingir ve Aydın (2017), Dündar Kurt (2019) ve Karaca ve Aslan (2019) da öğrencilerin sağlı algılarına yönelik yaptıkları araştırmalarında cinsiyet değişkeninin sağlık algısı üzerinden anlamlı etkisinin bulunmadığı sonucuna ulaşmışlardır. ${ }^{5,12,19-}$ ${ }^{21}$ Araştırmada cinsiyet değişkenine göre anlamlı farklılığın bulunmaması, örneklemde erkek katılımcı oranının göreceli olarak az olmasindan kaynaklanabilir. 
arkadaşlarıyla kalan öğrencilerin

Araştırmada sağlıklı beslenme durumu açısından her iki ölçekte de gruplar arasında anlamlı farklılık meydana gelmediği görülmüştür. $\mathrm{Bu}$ durum öğrencilerin bu soruya objektif cevap vermemiş olmalarından kaynaklanmış olabilir. Nitekim araştırmada öğrencilerin büyük bir çoğunluğu kısmen sağlıklı beslendiğini ifade etmiştir. Öğrenciler kısmen sağlıklı beslendiklerini düşünse de gerçekte beslenme tarzları sağlıklı olmayabilir. $\mathrm{Bu}$ nedenle bu sorunun daha ayrıntılı olarak sorulması gerektiği düşünülmektedir. Karaca ve Aslan (2019) da çalışmalarında öğrencilerin sağlıklı beslenme durumlarına göre sağlık algılarının farklılaşmadığ sonucuna ulaşmışlardır. ${ }^{21}$ Ancak Açıksöz ve diğerleri (2013) ise araştırmalarında öğrencilerin sağlık algılarını beslenme durumlarının etkilediğini bulmuşlardır. ${ }^{22}$

Araştırmada sınıf değişkeni bakımından her iki ölçekte de anlamlı farklılık meydana gelmiştir. Buna göre öğrencilerin sinıf düzeyleri arttıkça sağlık algısı düzeyleri de artış göstermektedir. Benzer şekilde Çilingir ve Aydın (2017) yaptıkları araştırmalarında sınıf değişkenine göre anlamlı farklılığın ortaya çıktığını saptamışlardır. ${ }^{12}$ Ayrıca Karaca ve Aslan (2019) yaptıkları çalışmada öğrencilerin sınıf düzeyi yükseldikçe sağlık algılarının da yükseldiğini bulmuşlardır. ${ }^{21}$ Dündar Kurt (2019) sağlık algısı ve stresle başa çıkma tarzlarına ilişkin yaptığ 1 araştırmada öğrencilerin sınıf düzeylerinin artmasının sağlık algılarını da artırdığ 1 sonucuna ulaşmıştır. ${ }^{20}$ Araştırmada öğrencilerin sınıf düzeyi arttıkça sağlık algısı düzeylerinde artış meydana gelmesi, alınan eğitimler sayesinde sağlık konusunda bilgi seviyelerinin artmasıyla açıklanabilir. Ayrıca stresin de aynı ölçüde artması, sınıf düzeyi yükseldikçe gerek eğitim sorumlulukları gerekse de son sinifa yaklaşma ve atanma kaygısı gibi durumlardan kaynaklı olabilir.

Barınma şekli değişkeni bakımından algılanan stres ölçeği puanları arasında anlamlı farklılık bulunduğu ve algıladıkları stres düzeylerinin ailesiyle kalanlardan daha yüksek olduğu tespit edilmiştir. Benzer şekilde Topkaya ve Meydan (2013) yaptıkları araştırmada ailesiyle birlikte yaşayan öğrencilerin stres düzeylerinin daha düşük olduğu sonucuna ulaşmışlardır. ${ }^{23}$ Göker, Yıldız, Karabacak ve Doğan (2015) da yalnız yaşayan ya da arkadaşlarıyla kalan öğrencilerin daha yüksek düzeyde stres ve psikolojik sorunlara sahip olduklarını bulmuşlardır. ${ }^{24}$ Ev ortamında ebeveynler çocuklarının pek çok sorumluluğunu üstlenebilmektedir ancak ev arkadaşlığı yapmak fazlasıyla sorumluluk gerektirmektedir. $\mathrm{Bu}$ nedenle arkadaşlarıyla kalan öğrencilerin stres düzeyleri daha yüksek çıkmış olabilir. Araştırmada Sağlık Algısı Ölçeği'nden alınan puanlarda barınma şekline göre anlamlı farklılık oluşmadığı görülmüştür. Öğrencilerin birlikte yaşadıkları kişilerin yaşam tarzlarının, sağlık algılarının vb. bilinmemesi sonucu etkilemiş olabilir. Dündar Kurt (2019) da sağlık algısı ve stresle başa çıkma tarzlarına ilişkin yaptığ araştırmada öğrencilerin barınma şekillerinin sağlık algıları üzerinde etkili olmadığı sonucuna ulaşmıştır. ${ }^{20}$

Sigara kullanma durumu bakımından Sağlık Algısı Ölçeği'nden alınan puanlar arasında farklılık bulunmadığı görülmüştür. Karaca ve Aslan (2019) öğrencilerin sağl1k algılarının sigara içme durumlarına göre farklılaşmadığ 1 sonucuna ulaşmışlardır. ${ }^{21}$ Buna karşılık Dündar Kurt (2019) sağlık algısı ve stresle başa çıkma tarzlarına ilişkin yaptığı araştırmada, sigara içen öğrencilerin sağlık algısı düzeylerinin daha düşük olduğu sonucuna ulaşmıştır. ${ }^{20}$ Benzer şekilde Lee (2019) sigara içme sıklığına bağlı olarak bireylerin sağlık algılarının azaldığını belirtmiştir. ${ }^{5}$ Araştırmada sigara kullanma durumunun Algilanan Stres Ölçeği'nden alınan puanlarda anlamlı farklılığa neden olduğu, sigara içme sıklığ1 arttıkça algılanan stres düzeyinin yükseldiği tespit edilmiştir. İnsanların sigara içmelerinin nedeni çoğu zaman yaşadıkları problemler (aile, iş vb.) olabilmektedir. 
strese neden olabilmektedir. ${ }^{6}$ Hastalık

Yaşanılan bu problemlerde strese neden olabilmektedir. Bu nedenle sigara içenlerin stres düzeyleri yükssek çıkmış olabilir. Ya da sigaranın sağlığa zararlı olduğunu bilmeleri öğrenciler üzerinden stres yaratıyor olabilir.

Araştırmada ailesinde kronik hastalık olma durumuna göre gruplar arasında anlamlı farklılık bulunmamıştır. Bu sonuç ailesinde kronik hastalığı olan öğrenci sayısının az olmasından kaynaklanabilir Bireyde kronik hastalık olma durumuna göre algılanan stres ölçeğinden alınan puanlarda farklılık meydana geldiği ancak sağlık algısı ölçeği puanları arasında farklılık bulunmadığı tespit edilmiştir. Çilingir ve Aydın (2017), Özdelikara vd. (2018) ile Karaca ve Aslan (2019) araştırmalarında öğrencilerin sağlık algılarının kronik hastalık durumuna göre farklılaşmadığı sonucuna ulaşmışlardır. ${ }^{12,19,21}$ Benzer şekilde Lee (2019) araştırmasında kronik hastalık durumunun, öğrencilerin sağlık algıs1 üzerinde etkili olmadığını belirtilmiştir. ${ }^{5}$ Kronik hastalığın türü, ne kadar süredir kronik hastalı̆̆a sahip olunduğu gibi değişkenlerin de önemli olduğu düşünülmektedir. Araştırmada kronik hastalık durumunun öğrencilerin stres algılarını etkilediği sonucuna ulaşılmıştır. Hastalık süreci, tedavi ve hastalığın gelecek yaşamı nasıl etkileyeceği kaygısı kişilerde olması durumunda stres düzeyinin yüksek olması araştırmada beklenen bir sonuçtur.

Araştırmada öğrencilerin algıladıkları stres düzeylerinin sağlık algısı düzeyleri üzerinde anlamlı etkiye sahip olduğu ve stres düzeyi artıkça sağlık algısını da arttığı sonucuna ulaşılmıştır. Özdelikara ve diğerleri (2018) yaptıkları araştırmada öğrencilerin sağlık algılarının, anksiyete düzeyleri üzerinde etkili olduğu sonucuna ulaşmışlardır. ${ }^{19}$ Benzer şekilde Karaca ve Aslan (2019) öğrencilerin sağlık algıları ile yaşadıkları stres düzeyleri arasında anlamlı ilișki belirlemișlerdir. ${ }^{21}$ Benzer şekilde Lee (2019) öğrencilerin sağlık algılarına yönelik yaptığı araştırmada stresin sağlık algısı üzerinden anlamlı etkisinin bulunduğu belirtilmiştir. ${ }^{5} \quad \mathrm{Bu}$ araştırmalardaki bulguların aksine, Dündar Kurt (2019) stresle başa çıkma ve sağlık algısına ilişkin yaptığı araştırmada öğrencilerin stresle başa çıkma tarzları ve sağlık algısı arasında anlamlı ilişkinin ortaya çıkmadığı sonucuna ulaşmıştır. ${ }^{20}$ Araştırmada öğrencilerin stres düzeylerinin sağlık algıları üzerinde etkili olması beklenen bir durumdur. Çünkü ilgili literatürdeki çalışmalar ve kuramsal çerçeve incelendiğinde, yoğun yaşanan stresin birçok fizyolojik, psikolojik ve biyolojik rahatsızlıklara neden olabileceği ve bireylerin sağlık algısı üzerinde etkili olabileceği belirtilmektedir.

\section{SONUÇ VE ÖNERİLER}

Araştırmada öğrencilerin algılanan stres ve sağlık algısı ölçeğinden aldıkları puanlar cinsiyet, ailede kronik hastalık durumu ve sağliklı beslenme durumu açısından incelendiğinde gruplar arasında anlamlı farklılığın ortaya çıktığı saptanmıştır. Algılanan stres ölçeği puanlarında barınma şekli, sigara içme durumu, bireyde kronik hastalık durumu açısından anlamlı farklılık meydana gelmesine karşılık sağlık algısı ölçeği puanları arasında farklılık bulunmamıştır. Anlamlı farklılık meydana gelen gruplarda ise arkadaşlarıyla kalan öğrencilerin ve kronik hastalığı olan öğrencilerin algılanan stres düzeylerinin daha yüksek olduğu, sigara içme sıklığ 1 arttıkça algılanan stres düzeyinin yükseldiği sonucuna ulaşılmıştır. Araştırmada sınıf değişkeni bakımından her iki ölçekte de anlamlı farklılık meydana gelmiştir. Buna göre öğrencilerin sınıf düzeyleri arttıkça stres düzeyleri ve sağlık algısı düzeyleri de artış göstermektedir. Araştırmada öğrencilerin sağlık algıları ve stres düzeylerinin birbirini anlamlı düzeyde etkilediği tespit edilmiştir. $\mathrm{Bu}$ sonuçlar dikkate alınarak öğrencilere sağlık algılarını desteklemeye yönelik eğitimler verilebilir, 
eğitim müfredatlarına sağlık algısı ile ilgili dersler eklenebilir. Stres yönetimi konusunda öğrencilere danışmanlık verilebilir. Algılanan stres ve sağlık algısı farklı örneklem gruplarında farklı değişkenler açısından incelenebilir.

\section{KAYNAKLAR}

1. Çapık, C. (2006). Yoksul ve Yoksul Olmayan Kadınlarda Sağlık Algısını Etkileyen Etmenlerin İncelenmesi. Dokuz Eylül Üniversitesi Sağlık Bilimleri Enstitüsü, Yüksek Lisans Tezi, İzmir

2. Caka, Y., Topal, S. S., Suzan, Ö. K., Cınar, N., Altınkaynak, S. (2017). "Hemşirelik Öğrencilerin Sağlık Algısı İle Özgüvenleri Arasındaki İlişki.” Journal Human Rhythm, 3 (4), 199-203.

3. Kocaakman, M., Aksoy, G., Eker, H. H. (2010). "İstanbul İlindeki Hemșirelik Yüksekokulu Öğrencilerinin Sağlıklı Yaşam Biçimi Davranışları.” SDÜ Tıp Fak Dergisi, 17, 19-24.

4. Karabulutlu. EY., Karaman, S. (2015). "Kanser Hastalarında Hastalık Algısının Değerlendirilmesi." Journal of Health Science and Profession, 2, 271-84.

5. Lee, C. M. (2019). "The Influence of Perceptions of the Campus Environment and Health Perception on Stress of Nursing College Students.” Journal of Digital Convergence, 17 (2), 329-338

6. Alkan, A. S., Özdelikara, A., Boğa, M. N. (2017). "Hemșirelik Öğrencilerinin Sağlık Algılarının Belirlenmesi.” Gümüşhane Üniversitesi Sağlık Bilimleri Dergisi, 6 (2), 11-21.

7. Eser, S., İkinci, S., Ocaktan, M.E., Calışkan, D., Piyal, B., Akdur, R. (2012). "Eczacılık Fakültesi Öğrencilerinde Sağlık Algısının Değerlendirilmesi.” 15. Ulusal Halk Sağlığı Kongresi Özet Kitab1, 592-4.

8. Kaya, M., Genç, M., Kaya, B., Pehlivan, E. (2007). "Tıp Fakültesi ve Sağlık Yüksekokulu Öğrencilerinde Depresif Belir Yaygınlığı, Stresle Başa Çıkma Tarzları ve Etkileyen Faktörler.” Türk Psikiyatri Dergisi, 18 (2), 137-146.

9. Çalışkan, S., Aydoğan, S., Işıklı, B., Metintaş, S., Yenilmez, F., Yenilmez, Ç. (2018). "Üniversite Öğrencilerinde Algılanan Stres Düzeyi Ve İlişkili Olabilecek Faktörlerin Değerlendirilmesi." Türk Dünyası Uygulama ve Araştırma Merkezi Halk Sağlığı Dergisi, 3 (2), 40-9.

10. Zaybak, A. ve Fadıloğlu, C. (2004). "Üniversite Öğrencilerinin Sağlığı Geliştirme Davranışı Ve Bu Davranışı Etkileyen Etmenlerin Belirlenmesi." Ege Üniversitesi Hemşirelik Yüksekokulu Dergisi, 20 (1), 77-95.

11. Kadığlu, H. ve Yıldız, A. (2012). "Sağlık Algısı Ölçeği’nin Türkçe Cevriminin Geçerlilik Ve Güvenilirliği." Türkiye Klinikleri Tıp Bilimleri Dergisi, 32 (1), 47-53

12. Çilingir, D. ve Aydın, A. (2017). "Hemșirelik Bölümünde Öğrenim Gören Öğrencilerin Sağlık Algısı.” FNJN Florence Nightingale Hemşirelik Dergisi, 25 (3), 167-176.

13. Anna, S., Anette, S., Maja, S. (2016). "Younger Children's (Three to Five Years) Perceptions of Being in a Health-Care Situation." Early Child Development and Care, 186 (5), 832844.

14. Tara, M., Joseph, W., Alexandra, H., Rachel, R., Daniel, M. (2014). "Teacher Reports of Student Health and Its Influence on Students' School Performance." Journal of Positive Behavior Interventions, 16 (2), 112-122.

15. Karadağ, E. (2010). "Eğitim Bilimleri Doktora Tezlerinde Kullanılan Araștırma Modelleri: Nitelik Düzeyleri Ve Analitik Hata Tipleri." Kuram ve Uygulamada Eğitim Yönetimi (Educational Administration: Theory and Practice), 16 (1), 4971 .
16. Cohen S, Kamarck T, Mermelstein S (1983). "A Global Measure of Perceived Stress.” J Health Soc Behav, 24, 38596.

17. Erci, B. (2006). "Reliability And Validity Of The Turkish Version Of Perceived Stress Scale.” Atatürk Üniv. Hemşirelik Yüksekokulu Dergisi, 9 (1)

18. Diamond, J., Julie A, B., Christine A, A., Christopher, C., Michaek P, R. (2007). "Development of a Scale to Measure Adults' Perceptions of Health: Preliminary Findings." Journal of Community Psychology, 35 (5), 557-561.

19. Özdelikara, A., Ağaçdiken Alkan, S., Mumcu, N. (2018). "Hemşirelik Öğrencilerinde Sağlık Algısı, Sağlık Anksiyetesi ve Etkileyen Faktörlerin Belirlenmesi." Bakırköy Tıp Dergisi, $14,275-82$.

20. Dündar Kurt, G. (2019). Çıraklık Eğitimi Gören Adölesanların Sağlık Algısı Ve Stresle Başa Çıkma Tarzları. Marmara Üniversitesi Sağlık Bilimleri Enstitüsü, Yüksek Lisans Tezi, İstanbul.

21. Karaca, T., Aslan, S. (2019). "Hemşirelik Öğrencilerinin Sağlık Durumu Algılarının ve Sağlıklı Yaşam Biçimi Davranışlarının Belirlenmesi." ACU Sağlık Bil. Dergisi, 10 (4), 734-739.

22. Açıksöz, S., Uzun, Ş. ve Arslan, F. (2013). "Hemşirelik Öğrencilerinin Sağlık Algısı İle Sağlığı Geliștirme Davranışları Arasındaki İlişskinin İncelenmesi.” Gülhane Tıp Dergisi, 55 (3), 181-187.

23. Topkaya, N. ve Meydan, B. (2013). “Üniversite Öğrencilerinin Problem Yaşadıkları Alanlar, Yardım Kaynakları Ve Psikolojik Yardım Alma Niyetleri." Trakya Üniversitesi Eğitim Fakültesi Dergisi, 3 (1), 25-37.

24. Göker, K., Yıldız, H., Karabacak, E. ve Doğan, B. (2015). "Türkiye'de Calıșan Dermatologların Tamamlayıcı ve Alternatif Tıp Yöntemleri Hakkında Bilgi ve Yaklaşımları.” TÜRKDERM, 49, 31-36. 